\title{
23. REWORKED MIDDLE CRETACEOUS ORBITOLINID FORAMINIFERS FROM SOUTHEASTERN GULF OF MEXICO (DEEP SEA DRILLING PROJECT LEG 77, SITE 535) ${ }^{1}$
}

\author{
Antonietta Cherchi, Istituto di Geologia e Paleontologia dell' Università di Cagliari, Italy \\ and \\ Rolf Schroeder, Geologisch-Paläontologisches Institut der Universität Frankfurt a.M., Germany
}

\section{INTRODUCTION}

During Leg 77, coarse calcarenites with shallow-water debris containing orbitolinid foraminifers were recovered at Site 535 in the southeastern Gulf of Mexico (latitude $23^{\circ} 42.48^{\prime} \mathrm{N}$, longitude $84^{\circ} 30.97^{\prime} \mathrm{W}$ ).

Orbitolinid foraminifers were found in Cores 535-22 and 535-23. They occur in association with Favusella cf. washitensis, Nummoloculina heimi, Cuneolina sp., frequent fragments of pachydont pelecypods, rare echinoderm fragments, and dasycladacean algae (Acicularia sp.).

We have studied orbitolinids from Samples 535-22-6, 58-63 cm; 535-22,CC; and 535-23-1, 17-21 cm. Despite the very poor preservation, we could determine the following species: Dictyoconus walnutensis, Paracoskinolina $\mathrm{cf}$. sunnilandensis, and Orbitolina (Mesorbitolina) texana or $O$. (Mesorbitolina) parva.

\section{SYSTEMATIC DESCRIPTION}

Family ORBITOLINIDAE Martin, 1889

Genus DICTYOCONUS Blanckenhorn, 1900

Dictyoconus walnutensis (Carsey), 1926

(Plate 1, Figs. 1-3)

Orbitolina walnutensis Carsey, 1926, p. 23, pl. 7, figs. 11a-b; pl. 8, fig. 3.

Dictyoconus aegyptiensis (Chapman) var. walnutensis (Carsey). Silvestri, 1932 , p. 377 , pl. 1, figs. 10-12; pl. 2, figs. 3-5.

Dictyoconus walnutensis (Carsey). Davies, 1939, pp. 775-776, pl. 1, figs. 4, 6; Maync, 1955b, pp. 85-88, pl. 13, figs. 1-7; Douglass, 1960 b, pp. $257-258$, pl. 5 , figs. $1-8$.

Remarks. The dorsal surface of most specimens has been strongly eroded, removing most of the marginal zone. As the relatively short horizontal subepidermal plates seldom are preserved, at first sight the specimens could be confused with the morphologically similar Paracoskinolina sunnilandensis (Maync). However, better preserved parts of this zone show clearly that horizontal plates sometimes are present (Plate 1, Figs. 1-3; arrows). Moreover, the dimensions of our specimens are identical to topotypes obtained from Maync (1955b, p. 88), whereas those of Paracoskinolina sunnilandensis clearly are smaller (Maync, 1955a, p. 108).

Axial and subaxial sections of Dictyoconus walnutensis (Plate 1, Figs. 1-3) show that the central zone is subdivided by interseptal pillars alternating in position from one chamber to the next. On the contrary, pillars of Paracoskinolina sunnilandensis are essentially arranged in radial rows extending from the apex of test toward the last septum (Maync, 1955a, plate 17, figs. 1-3).

\footnotetext{
${ }^{1}$ Buffler, R. T., Schlager, W., et al., Init. Repts. DSDP, 77: Washington (U.S. Govt.
} Printing Office).

\author{
Genus PARACOSKINOLINA Moullade, 1965 \\ Paracoskinolina cf. sunnilandensis (Maync), 1955 \\ (Plate 1, Fig. 5)
}

cf. Coskinolina sunnilandensis Maync, 1955a, pp. 106-109, pl. 16, figs. $1-2,5$; pl. 17, figs. $1-2,4$.

Remarks. Tangential sections of two young specimens found in Sample 535-22,CC can be attributed with reserve to this species. One of them (Plate 1, Fig. 5) has a relatively large globular and slightly eccentric embryonic chamber with a diameter of $0.1 \mathrm{~mm}$ that is followed by a small cuneiform chamber (arrow). The marginal zone of the next five discoidal chambers is subdivided by primary vertical plates that generally are radially aligned. Marginal chamberlets may be subdivided by shorter and thinner secondary vertical plates.

The absence of horizontal subepidermal plates and the arrangement of vertical plates within the marginal zone indicate that the two tangential sections belong to Paracoskinolina sunnilandensis. However, as structural elements of the central zone are unknown, this determination is not certain.

Genus ORBITOLINA d'Orbigny, 1850 Subgenus MESORBITOLINA Schroeder, 1962

Orbitolina (Mesorbitolina) texana (Roemer), 1849 or parva Douglass, 1960

(Plate 1, Figs. 4, 6-7)

Remarks. Specimens belonging to Orbitolina (diameter of test: 2$2.5 \mathrm{~mm}$ ) are not rare but normally are so abraded that the embryonic apparatus of macrospheric forms, which is very important for an exact determination, is not preserved. Only two specimens still show embryonic structures (Plate 1, Figs. 4, 6-7).

The presence of a tripartite embryonic apparatus consisting of protoconch, deuteroconch, and subembryonic zone indicates that these two specimens belong to the genus Orbitolina. The subembryonic development of the apparatus is typical for the subgenus Mesorbitolina (Schroeder, 1962, p. 181). The diameter of embryonic structures (Plate 1, Fig. 6: $0.2 \mathrm{~mm}$; Fig. 7: $0.25 \mathrm{~mm}$ ) indicates that these specimens represent either $O$. (Mesorbitolina) parva or $O$. (Mesorbitolina) texana. However, these two species can be differentiated only by horizontal sections through the upper part of the subembryonic zone (Schroeder, 1979 , p. 291). In $O$. parva, the distance from the wall of the protoconch to the outer wall of the subembryonic zone generally is less than that between two adjacent radial septula of this zone. On the contrary, in $O$. texana, the distance from the wall of the protoconch to the outer wall of the subembryonic zone is equal to or greater than that between two radial septula. As these distance relationships are not visible in axial sections, the two figured specimens (Plate 1, Figs. 4, 6-7) cannot be determined unquestionably.

\section{AGE OF THE ORBITOLINID FORAMINIFERS}

Orbitolinid foraminifers are widespread in the bank and reef deposits of the Gulf Coast of the United States, Mexico, and the Caribbean islands.

According to Douglass (1960a, p. 6) and Coogan (1977, p. 38), Orbitolina ranges in this area from upper Aptian to basal middle Albian (Trinity group). Within.this time 
interval, the stratigraphic range of the two mentioned species can be fixed from the western Mediterranean region: $O$. (Mesorbitolina) parva is of late Aptian age (Schroeder, 1975, p. 123); its direct phylogenetic descendant, $O$. (Mesorbitolina) texana, ranges from late Aptian to middle Albian (Groupe de Travail, 1981, p. 385).

According to Coogan (1977, p. 38), Dictyoconus walnutensis occurs in the Fredericksburg Group (mainly mid-Albian). This species was also reported by Maync (1955b) from the basal Guácharo Limestone (Chimana Formation) of eastern Venezuela to which a middle Albian age is assigned (Rod and Maync, 1954).

Paracoskinolina sunnilandensis is of late Trinity age (early to early middle Albian) in the Gulf Coast area (Maync, 1955a, p. 110; Coogan, 1977, p. 38).

Samples 535-17, CC through Core 535-30 are middle Cenomanian, on the basis of ammonites. Therefore, the orbitolinid foraminifers found in Cores 535-22 and 535-23 can be considered as reworked.

\section{ACKNOWLEDGMENTS}

We wish to thank Professor Isabella Premoli Silva (University of Milan, Italy) for placing at our disposal the material studied in this chapter. We thank Professors A. R. Loeblich, Jr., and H. Loeblich Tappan (University of California, Los Angeles) for critical review of the manuscript.

\section{REFERENCES}

Carsey, D. O., 1926. Foraminifera of the Cretaceous of central Texas. Univ. Texas Bull. (Bur. Econ. Geol.), 2612:1-56.

Coogan, A. H., 1977. Early and Middle Cretaceous Hippuritacea (rudists) of the Gulf Coast. In Bebout, D. G., and Loucks, R. G.
(Eds.), Cretaceous Carbonates of Texas \& Mexico. Applications to Subsurface Exploration: Austin, Texas (Texas Univ. Bur. Econ. Geol.), pp. 32-70.

Davies, L. M., 1939. An early Dictyoconus, and the genus Orbitolina: their contemporaneity, structural distinction, and respective natural allies. Trans. R. Soc. Edinburgh, 59(3):773-790.

Douglass, R. C., 1960a. The foraminiferal genus Orbitolina in North America. U.S. Geol. Surv. Prof. Pap., 333:1-52. 1960b. Revision of the family Orbitolinidae. Micropaleontology, 6(3):249-270.

Groupe de Travail Européen des Grands Foraminifères, 1981. Tableau de répartition stratigraphique des grands foraminifères caractéristiques du Crétacé Moyen de la région méditerranéenne. Cretaceous Res., 2:383-393.

Maync, W., 1955a. Coskinolina sunnilandensis, n.sp., a Lower Cretaceous (Urgo-Albian) species. Contrib. Cushman Found. Foram. Res., 6(3):105-111. 1955b. Dictyoconus walnutensis (Carsey) in the Middle Albian Guácharo limestone of eastern Venezuela. Contrib. Cushman Found. Foram. Res., 6(3):85-96.

Rod, E., and Maync, W., 1954. Revision of Lower Cretaceous stratigraphy of Venezuela. Am. Assoc. Pet. Geol. Bull., 38(2):193-283.

Schroeder, R., 1962. Orbitolinen des Cenomans Südwesteuropas. $\mathrm{Pa}-$ laont. Z., 36(3-4):171-202.

1975. General evolutionary trends in orbitolinas. Rev. Esp. Micropaleontol., spec. vol., pp. 117-128.

1979. Les Orbitolines de l'Aptien: définitions, origine et évolution. Geobios, Mem. Spec., 3:289-299.

Silvestri, A., 1932. Revisione di orbitoline nordamericane e nuovi località di Chapmanine. Mem. Accad. Pont. Nuovi Lincei Ser. 2, 16: 371-394.

Date of Initial Receipt: April 11, 1983

Date of Acceptance: July 1, 1983 

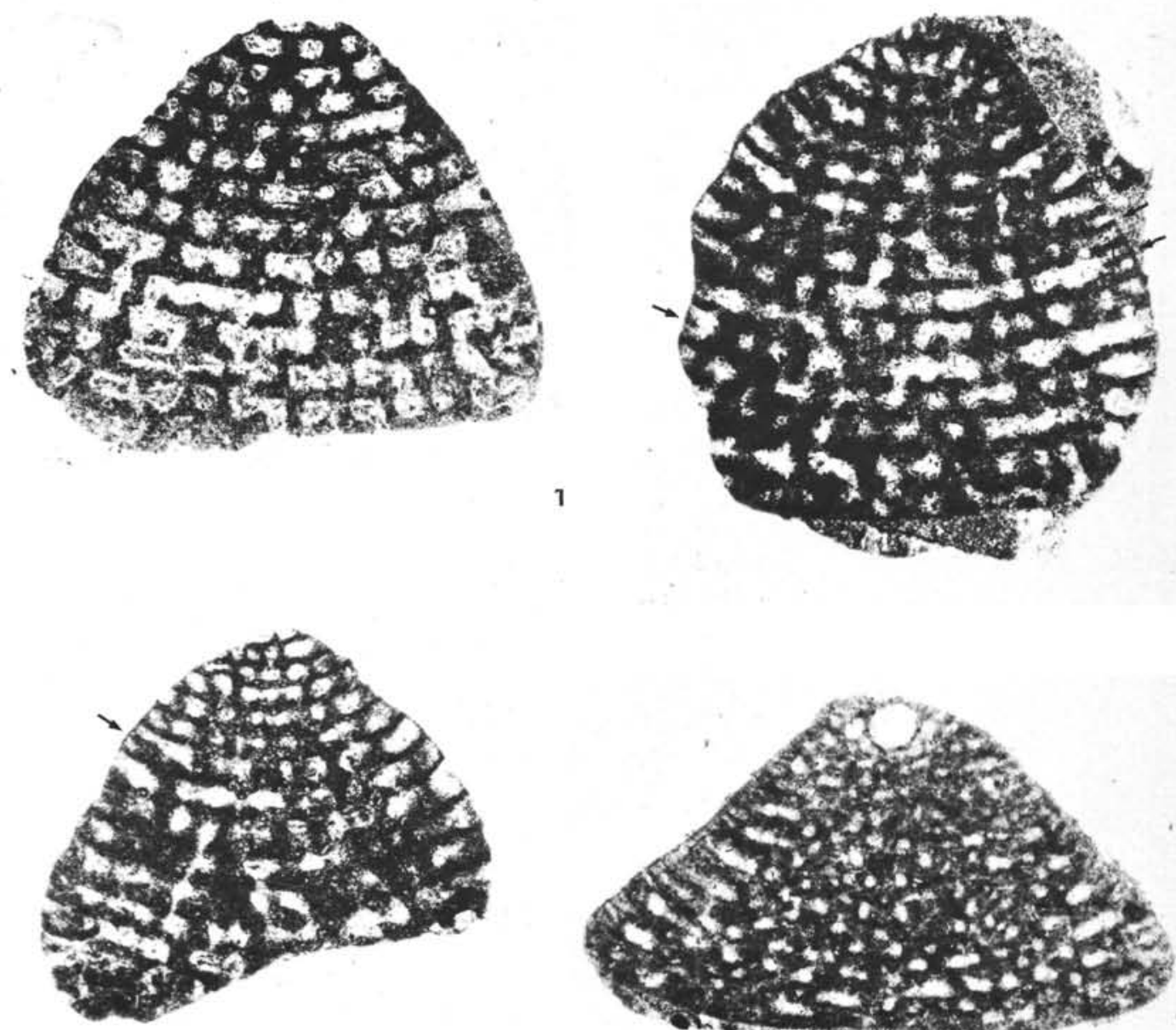

2

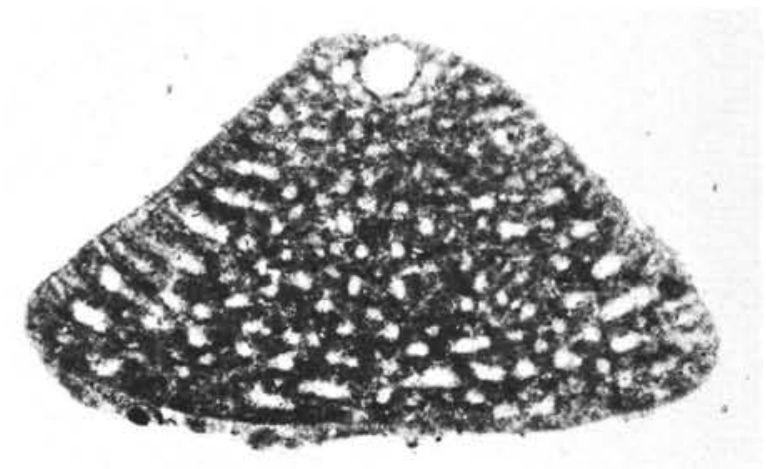

3
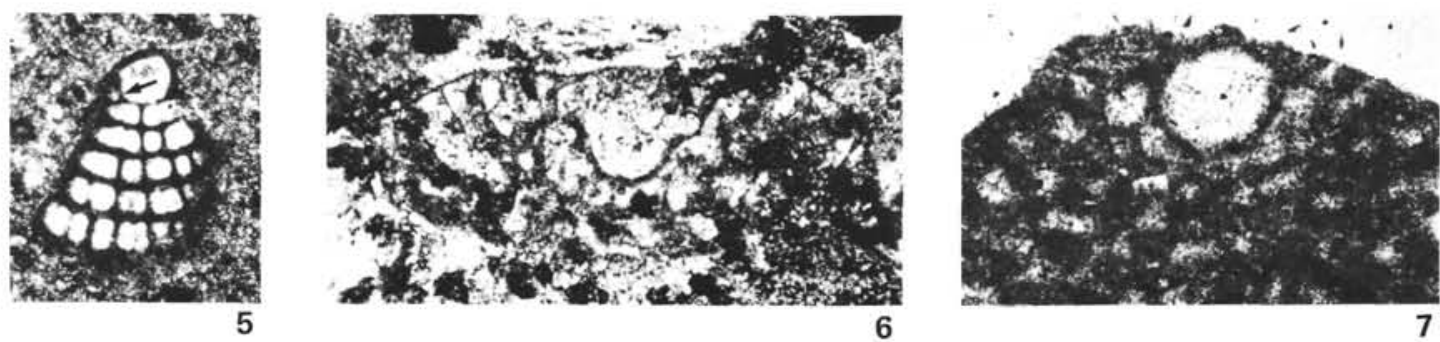

Plate 1. Reworked middle Cretaceous orbitolinid foraminifers from the southern Gulf of Mexico (DSDP Leg 77, Hole 535). 1-3. Dictyoconus walnutensis (Carsey). Cores 535-22/23, (1) subaxial section, $\times 50$, (2) oblique subaxial section, $\times 50$, (3) subaxial section, $\times 50$. Arrows point to horizontal plates of marginal zone. 4, 6-7. Orbitolina (Mesorbitolina) texana (Roemer) or parva Douglass, (4) axial section of a macrospheric specimen, $\times 50$ (Cores 535-22/23), (6) axial section of a young specimen showing embryonic apparatus, $\times 100$ (Sample 535-22, CC), (7) embryonic apparatus of the specimen figured on Fig. 4, $\times 100$. 5. Paracoskinolina $\mathrm{cf}$. sunnilandensis (Maync). Tangential section of a young specimen showing the embryonic chamber, $\times 50$ (Sample 535-22,CC). 